\section{ASPECTS OF STRUCTURAL ENGINEERING}

$\mathrm{T}$ HE Bossom Gift Lecture for the current session, forming part of the programme of public lectures arranged by the Chadwick Trust, was delivered on November 26, 1946, at the Institution of Structural Engineers by this year's president of that body, Prof. H. J. Collins, Chadwick professor of engineering at University College, London. Under the title of "Some Aspects of Structural Engineering", Prof. Collins dealt broadly with the post-war building situation in Britain, with special reference to the report of the mission (on which Sir Alfred Bossom, who presided at the meeting, had served) which visited the United States of America in 1943, to the present policy of the Government on housing, and to the 'avalanche of paper' in the form of building studies, codes, standard specifications and revised regulations with which those who design and construct in these days are expected to comply. Having but recently resumed civilian duties after five years of active service in the Royal Engineers, Prof. Collins chose to refer by question rather than by answer to certain aspects of building and constructional engineering which marked the contrast between post-war and pre-war years.

Prof. Collins said that six non-constructive, indeed extremely destructive, years had brought the urgency of the need for building to a tremendous pitch, intensified by the general desire that social conditions should in the process be improved. Domestic housing is undoubtedly of the first importance ; it is necessary to employ as economically as possible both labour and material, and to devise substitutes for all materials which are not indigenous. Types of construction other than housing are also urgently needed. When work on these is resumed :

What will be the effect, on the progress of construction, of uncertainties both as to construction dates and as to the loads and stresses which will then be permissible?

The economical use of materials is a measure of the skill of the engineer, but it takes from five to ten years to train a civil engineer, and none was being trained during the last three years of the War. It is therefore more than ever necessary to keep the knowledge of trained engineers up to date.

Are the results of advances in research being made readily available to the engineer ?

The supreme achievement in structural design is to attain simplicity approaching functional perfection. Under State control, the tendency might well be away from simplicity, but the attempt might nevertheless be made to overcome the shortage of engineers by standardizing methods of design. To control design by legislation must tend to change its governing principle from individual initiative and considered thought to rampant empiricism, and so put an end to scientific progress.

How far can standardization be carried without tending to kill initiative ? Should the establishment of such standards as might be necessary be made the responsibility, not of a Government department, but of the appropriate engineering professional institution?

Ruskin showed that ancient building was often made wonderful by the marriage of science and art.
Is the light of the Seven Lamps of Architecture so dim to-day, asked Prof. Collins, as to need the further illumination of some 174 building studies, codes and standards?

Can studies, codes and regulations do away with the need for independent architects and for properly qualified structural engineers ?

A national policy governing the design and construction of buildings must be based on one of two alternatives: either it might allow any person to call himself an engineer, control him by regulations, and maintain conformity to these by a system of inspectors: or it might restrict the making of designs to selected persons of proved competence, and insist that such persons be qualified by institutional examination and/or by registration. Hitherto, standards of qualification for inspectors and systems of inspection in different parts of the country have varied considerably.

Could we accept as sound a national uniform set of building regulations ? Would registration act more for the national good or for the benefit of one or more groups of professional men?

Prof. Collins recalled his experiences in 1939, when he assisted in forming Construction and Artisan Works Companies of the Corps of Royal Engineers from 600-800 building craftsmen who had answered the urgent call for volunteers in the Christmas broadcast of that year. He had served with those men in three theatres of war and lived with them for five years. By their training as apprentices, they had been made amenable to suggestion ; because of the pride each felt in his craft they required little supervision; because they were used to working under the supervision of foremen they accepted discipline automatically. If the spirit of these volunteer craftsmen were present in the building industry to-day, then delays in production must come from other causes than their lack of willingness to deliver the goods.

In the course of general post-war increases in wages in the building industry, perhaps semi-skilled workmen and labourers had been unduly favoured at the expense of the more highly skilled workmen.

Were the post-war differences between the wages of craftsmen and of unskilled labourers sufficient to offset the drawbacks and hardship involved in the long apprenticeship required of the skilled trades ?

In conclusion, Prof. Collins referred briefly to the present position of research in relation to modern building, and mentioned several promising lines of possible development : the use of photogrammetry in town and country planning, the application to structural engineering of electrical methods of measuring strains which have proved successful in the aircraft industry, and the application of supersonic frequencies to the measurement and consolidation of materials.

The outstanding work which has been done and is still being done by the Government research departments, and by the institutions which they sponsor, should be supplemented by a pool of apparatus for research purposes, and by grants of fellowships to men who, by combining with research a limited amount of teaching, would hand on knowledge both of facts and methods to a wide circle. These considerations led to his last question.

In post-war reconstruction and planning, are the universities and technical colleges playing their full 
part in the advancement of building science and of research in structural engineering?

Some of Prof. Collins' questions were purely rhetorical, and indicated no doubt as to the answer he might have given : others would be difficult indeed to answer at the present time; but all referred to problems which demand solution, and were aimed at stimulating thought and decision in those who must either take a lead in directing the future or perforce follow the direction of others less reticent.

Reading between the lines of Prof. Collins' questions, 'it is not difficult to trace the hope he had expressed with less reserve in the conclusion to his presidential address to the Institution of Structural Engineers a fow weeks previously, that the "young members will in the future live to see the sun rise over the unshackled initiative of structural engineers ; engineers who carry no fetters of Government regulation, no manacles of Local Authority restriction; but who have the free and unchecked initiative to plan and design that belongs by right to members of a profession that bears such heavy responsibility to society and to mankind".

\section{Stanley B. Hamilton}

\section{ANTIBIOTICS}

$\mathrm{T}$ HE number of publications which record work on antibiotics has become so large that frequent evaluations of the progress of our knowledge of these substances have become essential. A conference devoted to these substances was held by the New York Academy of Sciences in January 1946, and the papers have now been published (Ann. N.Y. Acad. Sci., 48, Art. 2, 31; 1946). It is impossible to summarize these papers here, but a note on them will indicate their scope. They are arranged in two sections, one microbiological, the other pharmacological.

Dr. S. A. Waksman introduces the former with a paper on the contributions made by the microbiologist. M. J. Johnson describes the metabolism of penicillin-producing moulds, and K. B. Raper discusses the development of improved forms of them. W. J. Robbins, F. Kavanagh and Annette Hervey discuss the production of antibiotic substances by Basidiomycetes, S. A. Waksman, A. Schutz and D. M. Reynolds write on the production of antibiotic substances by Actinomycetes, and J. W. Foster and H. B. Woodruff deal with antibiotic substances produced by bacteria.

The pharmacological section is, with the exception of an article on the pharmacology of penicillin by G. Rake and A. P. Richardson and one on its use in the United States Navy by W. W. Duemling, devoted to the pharmacology of streptomycin and streptothricin. The first article on this subject is by H. Molitor. In another article H. J. Robinson discusses the absorption, excretion and chemotherapy of these two substances. The action of streptomycin on various micro-organisms and its use for the treatment of some non-tuberculous infections are discussed by E. Pulaski, A. Kleinman and G. G. Duncan. Its action on the bacillus of tuberculosis has given rise to the hope that it will be useful for the treatment of this disease; but the article here printed by $H$. C. Hinshaw and W. H. Feldman on the use of streptomycin for the treatment of clinical and experimental tuberculosis emphasizes the opinion expressed in an "Annotation" in the British Medical Journal (906, Dec. 14, 1946), that "it is at present quite uncertain whether streptomycin will prove, in the long run, to have great therapeutic value in tuberculosis". The same "Annotation" announces that committees appointed by the Medical Research Council will, when enough streptomycin becomes available, conduct trials of streptomycin for the treatment of types of tuberculosis likely to give clear evidence of its uses and limitations, and also trials of its action on certain non-tuberculous infections. The same cautious opinion of its possible efficacy for the treatment of tuberculosis is expressed by Dr. P. D'Arcy Hart in his Mitchell Lecture delivered to the Royal College of Physicians (Brit. Med. J., 805 , Nov. 30, and 849, Dec. 7,1946 ) on the "Chemotherapy of Tuberculosis", a remarkable lecture with a full bibliography, which is discussed in an editorial article in the British Medical Journal (862, Dec. 7), together with the Harben Lectures on the same sub. ject delivered by Dr. W. H. Feldman, of the Mayo Clinic. An interesting recent paper by D. G. Madigan, P. N. Swift and G. Brownlee (Lancet, 9, Jan. 4, 1947) indicates that what these authors call "the potential and actual toxicity of streptomycin" needs to be watched and investigated further.

Brief reference may also be made to the address given to the American Chemical Society in October of last year by Dr. L. C. Craig, of the Rockefeller Institute for Medical Research. Dr. Craig described a new method of isolating various forms of penicillin which frees the chemist from dependence upon boiling and melting points. This method, which is called 'counter-current distribution', uses the partition coefficient, which is a ratio indicating the diffusibility of a substance into cell protoplasm. The method employs a system of multiple transfers of the substance being studied through a series of separating funnels, so that the mathematics of the binomial theorem may be applied to interpret the results. Dr. Craig claimed that the method has disclosed at least seven types of penicillin and has indicated that there are many more. The method has also been applied to synthetic antimalarial substances.

\section{G. LAPAgE}

\section{CANADIAN RESEARCH IN GEODESY AND GEOPHYSICS}

$T$ HE National Research Council of Canada has re-organised its Associate Committee on Geodesy and Geophysics (formed in 1945) and has given it authority to gather information on, and to direct and co-ordinate research in the field of, "geodesy and geophysies, including meteorology, hydrology, oceanography, seismology, vulcanology, magnetism, terrestrial electricity, tectonophysics, gravity, and any other subjects necessary to an integrated study of earth physics and geophysical prospecting". The chairman of the Committee is Prof. J. T. Wilson, professor of geophysics, University of Toronto.

The Committee is being provided with funds for the award of grants in aid of specific research projects to persons competent to direct work in this field and who have the required laboratory facilities at their disposal. Much of the work that interests the Committee is carried out as part of their normal duties by several Government departments and is paid for by those departments. 